\title{
РОЛЬ І ВКЛАД УКРАЇНСЬКОЇ ВІЙСЬКОВО-МЕДИЧНОЇ АКАДЕМІЇ У МЕДИЧНЕ ЗАБЕЗПЕЧЕННЯ ЗБРОЙНИХ СИЛ УКРАЇНИ ПІД ЧАС АТО/ООС
}

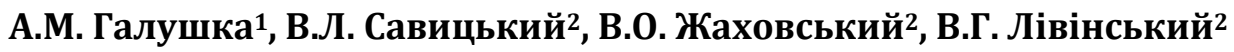 \\ ${ }^{1}$ Командування Медичних сил Збройних сил України м. Київ, Украӥна \\ гУкраїнська військово-медична академія м. Київ, Україна
}

\begin{abstract}
Мета роботи - дослідження ролі та вкладу Української військово-медичної академії (УВМА) у медичне забезпечення Збройних Сил (ЗС) України під час антитерористичної операції та операції Об'єднаних сил (АTO/OOC).

Матеріали та методи. Використано нормативно-правові акти з питань національної безпеки держави та охорони здоров'я в Україні, керівні документи Міністерства оборони України, публікації у відкритих наукових джерелах, щорічні звіти УВМА. Об'єкт дослідження - система підготовки медичного персоналу для Медичних сил Збройних Сил України (Медичні сили). Предмет дослідження - робота УВмА щодо підготовки медичного персоналу для Медичних сил та наукового супроводження розвитку системи медичного забезпечення ЗС Украӥни під час АТО/OОС. Методи дослідження - бібліографічний, статистичний, аналітичний, системного підходу.

Результати. Вклад УВМА в медичне забезпечення ЗС України не зводився лише до навчальної роботи з підготовки військових лікарів для потреб військових частин і військово-медичних закладів, а також був вагомим та значущим у таких напрямах діяльності військової медицини як практичне надання медичної допомоги пораненим, ураженим, травмованим і хворим військовослужбовцям у військово-медичних закладах в районах проведення АТО/ООС та на клінічних базах УВМА, в питаннях наукового супроводження розвитку системи медичного забезпечення ЗС України, у тому числі розроблення нормативно-правових $i$ керівних документів з медичного забезпечення, медико-технічних вимог сучасних зразків евакуаційнотранспортних засобів, спеціальної медичної техніки, комплектно-табельного оснащення Медичних сил та індивідуальних засобів медичного захисту.

Висновки. УВМА зроблено значний внесок у медичне забезпечення ЗС Украӥни під час АTО/OОС зокрема в питання комплектування Медичних сил підготовленим медичним персоналом, надання медичної допомоги пораненим, ураженим, травмованим і хворим військовослужбовцям та наукового вирішення проблем медичного забезпечення військ в умовах бойових дій.
\end{abstract}

Ключові слова: медичне забезпечення, військово-медична освіта та наука, УВМА.

Вступ. Важливою складовою системи медичного забезпечення збройних сил будьякої держави $\epsilon$ військово-медична освіта, яка разом із військово-медичною наукою є основою розвитку системи військової охорони здоров'я.

До системи військово-медичної освіти України належать навчальний заклад Українська військово-медична академія (УВМА) та кафедри медицини катастроф і військової медицини (КМК і ВМ) медичних закладів вищої освіти. Крім того, з метою підготовки для потреб Збройних Сил (3С) України стрільців-санітарів, бойових та старших бойових медиків, а також санітарних інструкторів створено 205 Навчальний центр тактичної медицини (205 НЦТМ).

Одним із пріоритетів розвитку системи медичного забезпечення, визначених Концепцією розвитку сектору безпеки і оборони України, є удосконалення системи підготовки та перепідготовки військово-медичних кадрів шляхом створення єдиної міжвідомчої системи підготовки та перепідготовки медичних кадрів для 3С України та інших військових формувань, запровадження в системі медичної освіти держави військово-медичної підготовки студентів та учнів, які освоюють медичні (фармацевтичні) спеціальності, щодо навчання стандартам надання медичної допомоги при бойовій травмі (патології) [1].

У Воєнно-медичній доктрині України питання підготовки медичного персоналу для потреб ЗС України та інших військових формувань присвячений окремий розділ, в якому зокрема наголошується, що підготовка та післядипломна освіта фахівців для потреб військово-медичних служб здійснюються в УВМА за єдиним державним замовленням, а також на КМК і ВМ у закладах вищої медичної освіти [2].

Тривалий збройний конфлікт на сході України виявив основні проблеми в системі медичного забезпечення ЗС України, зокрема низьку укомплектованість військовими 
лікарями медичних підрозділів військових частин, яка на початку антитерористичної операції (АТО) становила 65 \% [3].

3 метою прискореного комплектування лікарських посад у медичних підрозділах військових частин УВМА провела з 2014 року чотири дострокових та три чергових випуски слухачів факультету підготовки військових лікарів (ФПВЛ), всього 745 осіб за спеціальностями 254 «Забезпечення військ (сил)», 222 «Медицина», 221 «Стоматологія», 226 «Фармація, промислова фармація».

Водночас вклад УВМА в медичне забезпечення ЗС України не зводився до лише навчальної роботи 3 підготовки військових лікарів для потреб військових частин i військово-медичних закладів, а також був вагомим та значущим у таких напрямах діяльності військової медицини як практичне надання медичної допомоги пораненим, ураженим, травмованим i хворим військовослужбовцям у військово-медичних закладах в районах проведення антитерористичної операції та операції об'єднаних сил (АТО/ООС) та на клінічних базах УВМА, в питаннях наукового супроводження розвитку системи медичного забезпечення 3С України, у тому числі розроблення нормативно-правових і керівних документів 3 медичного забезпечення, медико-технічних вимог сучасних зразків евакуаційнотранспортних засобів, спеціальної медичної техніки, комплектно-табельного оснащення Медичних сил Збройних Сил України (Медичні сили) та індивідуальних засобів медичного захисту.

Мета роботи полягає в дослідженні ролі та вкладу УВМА у медичне забезпечення ЗС України під час проведення АТО/ООС.

Матеріали та методи. Використано нормативно-правові акти з питань національної безпеки держави та охорони здоров'я в Україні, керівні документи Міністерства оборони (МO) України, публікації у відкритих наукових джерелах, щорічні звіти УВМА. Об'єкт дослідження: система підготовки медичного персоналу для Медичних сил. Предмет дослідження: робота УВМА щодо підготовки медичного персоналу для Медичних сил та наукового супроводження розвитку системи медичного забезпечення ЗС України під час ATO/OOC. Методи дослідження: бібліографічний, статистичний, аналітичний, системного підходу.

Результати дослідження та їх обговорення. УВМА $\epsilon$ вищим військовомедичним навчальним закладом IV (четвертого) рівня акредитації, що провадить підготовку фахівців з вищою освітою другого, третього та наукового рівнів. Основним напрямом діяльності УВМА $\epsilon$ підготовка військовомедичних фахівців з вищою медичною освітою, їх перепідготовка і підвищення кваліфікації для потреб ЗС України та інших військових формувань, утворених відповідно до законів України, а також правоохоронних органів i збройних сил іноземних держав, військова підготовка громадян України за програмою підготовки офіцерів медичної служби запасу.

УВМА призначена для провадження освітньої, наукової, науково-технічної та інноваційної діяльності; провадження лікувально-діагностичної роботи, що пов'язана 3 наданням якісної медичної допомоги військовослужбовцям, ветеранам військової служби та іншим категоріям пацієнтів на клінічних базах УВМА відповідно до законодавства.

Освітню діяльність в УВМА організовано відповідно до вимог Закону України «Про вищу освіту» [4], «Положення про вищі військові навчальні заклади» [5], «Положення про особливості організації освітнього процесу у вищих військових навчальних закладах Міністерства оборони України та військових навчальних підрозділах вищих навчальних закладів України» [6], наказів і директив МО України, начальника Генерального штабу Головнокомандувача Збройних Сил України, а також наказів Міністерства освіти і науки України.

УВМА має право проводити підготовку фахівців за такими ступенями вищої освіти: магістр (вища медична освіта, вища військова освіта тактичного та оперативно-тактичного рівнів); доктор філософії; доктор медичних наук.

УВМА має належним чином оформлену ліцензію на право проведення освітньої діяльності щодо:

підготовки лікарів (провізорів) спеціалістів за фахом і магістрів оперативно-тактичного рівня, тактичного рівня у галузі знань 22 «Охорона здоров'я» зі спецільностей: 222 «Медицина», 221 «Стоматологія», 226 «Фармація, промислова фармація», в галузі знань 25 «Воєнні науки, національна безпека, безпека державного кордону» зі спеціальності 254 «Забезпечення військ (сил)»;

підвищення кваліфікації медичних фахівців у галузі знань 22 «Охорона здоров'я» зі спеціальностей: 222 «Медицина», 221 «Стоматологія», 226 «Фармація, промислова фармація»;

військову підготовку студентів вищих 
навчальних закладів за програмою офіцерів запасу;

підготовку докторів філософії у галузі знань 22 «Охорона здоров'я» зі спеціальностей: 222 «Медицина», 226 «Фармація, промислова фармація».

За час АTO/OOC на факультеті підготовки військових лікарів (ФПВЛ) УВМА підготовлено 745 офіцерів медичної служби, у тому числі по роках: 2014 рік - 81, 2015 рік - 77, 2016 рік - 79, 2017 рік - 98, 2018 рік - 105, 2019 рік - 145, 2020 рік - 160 осіб.

За спеціалізаціями випускники УВМА розподілилися таким чином (осіб):

організація медичного забезпечення військ

(сил) - 59;

хірургія - 137;

анестезіологія - 75;

загальна практика-сімейна медицина (для CB) - 171;

загальна практика-сімейна медицина (для ПС) - 36;

загальна практика-сімейна медицина (для BMC) - 28;

внутрішні хвороби - 129;

інфекційні хвороби - 12;

епідеміологія - 13;

загальна гігієна - 9;

стоматологія - 30;

загальна фармація - 46.

Детальний аналіз показників роботи УВМА по роках свідчить, що у 2013-2014 навчальному році на ФПВЛ навчалося 190 слухачів 3 8 лікарських та 1 фармацевтичної спеціалізації, а на факультеті перепідготовки і підвищення кваліфікації (ФППК) - 2411 слухачів із них лікарів 1 411, $з$ них на циклах тематичного удосконалення (ТУ) - 898 осіб, на передатестаційних циклах (ПАЦ) - 296 осіб, циклах спеціалізації (СП) - 153 особи, підтвердження сертифікату - 64 особи; молодших медичних спеціалістів 1000 осіб, на виїзних циклах пройшли навчання 508 осіб, 3 них 168 лікарів та 340 - молодший медичний персонал [7].

За програмою підготовки офіцерів медичної служби запасу проходили навчання 1620 студентів I-IV факультетів та стоматологічного факультету Національного медичного університету (НМУ) ім. 0.0. Богомольця, Київського медичного університету Української асоціації народної медицини (КМУ УАНМ) та Міжнародної академії екології і медицини (MAEiM).

У 2014 році закінчили повний курс навчання 76 слухачів ФПВЛ і два ад’юнкта. Крім того, в УВМА навчалися на договірних засадах 879 осіб, із них за формами навчання: магістратура - 16 осіб, інтернатура - 465 осіб, перепідготовка і підвищення кваліфікації 398 осіб.

В 2014-2015 навчальному році на ФПВЛ навчалося 209 слухачів з 9 лікарських та однієї фармацевтичної спеціалізації, а на ФППК 2475 слухачів, у тому числі 1715 лікарів, із них на циклах ТУ - 820 осіб, на ПАЦ - 647 осіб, циклах СП - 210 осіб, підтвердження сертифікату 38 осіб; молодших медичних спеціалістів 760 осіб [8]. На виїзних циклах пройшли навчання 766 осіб, з них 263 лікаря та 503 особи молодшого медичного персоналу.

У цьому навчальному році продовжувалася практика надання платних освітніх послуг. На договірних засадах в УВМА навчалося 1538 осіб, у тому числі за формами навчання: магістратура - 9; інтернатура - 427 осіб; перепідготовка і підвищення кваліфікації - 1102 особи.

У 2015 році відбувся достроковий випуск 77 слухачів ФПВЛ та 2 ад юнктів.

В 2015-2016 навчальному році на ФПВЛ навчалося 243 слухача з 9 лікарських та однієї фармацевтичної спеціалізації [9]. На ФППК навчались: на циклах СП (лікарі) - 586 осіб (з них для ЗС України - 196 осіб), на ПАЦ - 811 осіб (з них для ЗС України - 465 осіб), на циклах ТУ 1019 осіб (з них для 3С України - 632 особи), підтвердження сертифікату - 519 осіб (з них для 3С України - 87 осіб), на циклах СП (медичні сестри) - 110 осіб (з них для 3С України 53 особи), циклах ТУ (медичні сестри) 491 особа (з них для ЗС України - 260 осіб.

За програмою підготовки офіцерів медичної служби запасу проходили навчання 1293 студенти I-IV факультетів та стоматологічного факультету НМУ ім. О.О. Богомольця, КМУУАНМ та MAEiM. В УВМА навчалися на договірних засадах 1733 особи, з них за формами навчання: магістратура - 21; інтернатура - 256; перепідготовка і підвищення кваліфікації 1456 осіб.

У 2016 році відбувся достроковий випуск 81 слухача ФПВЛ та 3 ад`юнктів.

У 2016-2017 навчальному році на ФПВЛ навчалося 267 слухачів для ЗС України та 17 слухачів для інших військових формувань 3 9 лікарських та однієї фармацевтичної спеціалізації тактичного рівня підготовки, а також однієї спеціалізації оперативнотактичного рівня підготовки [10]. Підвищення кваліфікації на ФППК пройшли 2279 осіб.

В УВМА активно застосовувалася практика виїзних циклів на базі військово-медичних 
клінічних центрів (ВМКЦ) регіонів. Так, протягом 2017 навчального року на виїзних циклах пройшли підготовку 687 осіб, з них 347 лікарів та 340 молодших спеціалістів 3 медичною освітою. Вперше в районах проведення АТО/ООС на базі військових мобільних госпіталів (ВМГ) були проведені виїзні цикли ТУ для 81 медичного фахівця.

В УВМА навчалися на договірних засадах 1680 осіб, 3 них за формами навчання: магістратура - 6; інтернатура - 231 особа; перепідготовка і підвищення кваліфікації 1935 осіб. У 2017 році відбувся достроковий випуск 98 слухачів ФПВЛ та одного ад’юнкта.

За організаційного та методичного керівництва УВМА 15 травня 2017 року створено 205 НЦТМ, в якому розпочато підготовку військовослужбовців за програмою курсу «Фахова підготовка санітара взводу. Домедична допомога в умовах бойових дій». Базовим курсом у 205 НЦТМ був визначений курс підготовки медичних фахівців на основі стандарту $68 \mathrm{~W}$ Combat Medic (США).

У 2017-2018 навчальному році на ФПВЛ навчалося 287 слухачів для 3С України та 16 слухачів для інших військових формувань 3 9 лікарських та однієї фармацевтичної спеціалізації тактичного рівня підготовки, а також однієї спеціалізації оперативнотактичного рівня підготовки [11].

Підвищення кваліфікації на ФППК пройшли 2023 медичних фахівця, а План комплектування ФППК УВМА на 2018 рік (затвердженим заступником Міністра оборони України 27 грудня 2017 року) виконаний на $100 \%$. В цей період в УВМА навчалися на договірних засадах 2044 особи, з них за формами навчання: магістратура - 8 осіб; інтернатура - 275 осіб; перепідготовка і підвищення кваліфікації 1761 особа.

В 2018 році відбувся достроковий випуск 105 слухачів ФПВЛ та 2 ад’юнктів.

В 2018-2019 навчальному році на ФПВЛ навчалося 10 слухачів (очна форма) та 44 слухача (заочна форма) для ЗС України, 4 слухача (заочна форма) для інших військових формувань оперативно-тактичного рівня підготовки, 285 слухачів для 3С України, 24 слухача для Національної гвардії (НГ) України, 15 слухачів для Державної прикордонної служби (ДПС) України, 4 слухача для Державної служби спеціального транспорту (ДССТ) Міністерства інфраструктури України та 15 слухачів навчалося в клінічній ординатурі на ФППК з 8 лікарських та однієї фармацевтичної спеціалізації [12].
Підвищення кваліфікації на ФППК пройшли 2445 медичних фахівців, 3 них: лікарі (провізори) - 1506 осіб (СП - 192 особи, ТУ 633 особи, ПАЦ - 681 особа); молодші спеціалісти - 939 осіб (СП - 172 особи). В УВМА продовжується застосовування практики виїзних циклів на базах ВМКЦ регіонів. За 20182019 навчальний рік на виїзних циклах пройшли підготовку 623 особи, з них 257 лікарів та 366 молодших спеціалістів 3 медичною освітою.

Продовжується практика надання платних освітніх послуг і за 2018-2019 навчальний рік в УВМА провчилося на договірних засадах 2148 осіб, 3 них за формами навчання: магістратура - 12 осіб; інтернатура - 132 особи; перепідготовка і підвищення кваліфікації 2004 особи.

У 2019 році відбувся випуск 138 слухачів ФПВЛ, та 7 клінічних ординаторів.

За 2018-2019 навчальний рік 114 слухачів (для порівняння у попередньому навчальному році - 40 осіб), у тому числі 26 лікарів-хірургів, 15 лікарів-анестезіологів, 57 лікарів загальної практики та 16 лікарів-терапевтів, проходили лікарську практику у ВМГ безпосередньо в районах проведення АТО/ООС.

В 2019-2020 навчальному році на ФПВЛ навчалося 8 слухачів (очна форма) та 60 слухачів (заочна форма) оперативно-тактичного рівня підготовки, 295 слухачів для 3С України, 16 слухачів для НГ України, 17 слухачів для ДПС України, 6 слухачів для ДССТ МО України тактичного рівня підготовки з 8 лікарських та 1 фармацевтичної спеціалізації [13]. Відбувся випуск 160 слухачів ФПВЛ та 8 клінічних ординаторів.

Через світову пандемію гострої респіраторної хвороби COVID-19, спричиненої коронавірусом SARS-CoV-2 план комплектування ФППК на 2020 рік виконаний на $68 \%$, пройшло навчання 2450 осіб із 3607 осіб згідно плану. На виїзних циклах пройшли підготовку 560 осіб, з них 180 - лікарі та 380 молодші спеціалісти з медичною освітою. Також за дистанційною формою навчання пройшли підготовку 423 особи, з них 399 - лікарів та 24 молодших спеціаліста з медичною освітою.

У зв'язку з карантинними заходами у 20192020 навчальному році у ВМГ в районах проведення АТО/ООС лікарську практику проходили лише 16 слухачів.

Водночас починаючи з 2013 року вже традиційними стали щорічні тактико-спеціальні заняття зі слухачами УВМА в польових умовах на базі 169 Навчального центру Сухопутних військ 
3С України (смт. Десна) із розгортанням передових етапів медичної евакуації та залученням бойової i санітарної техніки в умовах максимально наближених до бойових 3 урахуванням досвіду, отриманого під час АTO/OOC. Одночасно слухачі першого курсу ФПВЛ УВМА тут же на полігоні проходять 1тижневий навчальний курс 3 тактичної медицини.

На виконання Плану прийому в 2020 році слухачів, курсантів (студентів) до вищих навчальних закладів для підготовки військових фахівців тактичного рівня на ФПВЛ УВМА прийнято 121 особу для ЗС України та 22 особи для інших військових формувань, у тому числі: 8 осіб для НГ України і 14 осіб для ДПС України. На оперативно-тактичний рівень підготовки за денною формою навчання зараховано 6 слухачів, також на навчання зараховано 2 ад'юнкта за спеціалізаціями «Терапія» та «Хірургія».

Відповідно до спільної директиви Міністра оборони України та Генерального штабу Збройних Сил України від 03.07.2014 року з метою організації перепідготовки та підвищення кваліфікації військовослужбовців в особливий період за військово-обліковими спеціальностями медичної служби ЗС України у складі УВМА як окремий структурний підрозділ утворено 8-і курси перепідготовки та підвищення кваліфікації медичного складу (8-і курси ППКМС).

8-і курси ППКМС проводять підготовку та перепідготовку офіцерів запасу, прийнятих на військову службу в умовах мобілізації, офіцерів запасу, прийнятих на військову службу за контрактом, офіцерів-резервістів першої та другої черги оперативного резерву (ОР 1, OP 2), а також осіб сержантського (старшинського) складу 3 вищою медичною освітою на отримання первинного офіцерського звання «молодший лейтенант медичної служби». Усі зазначені категорії проходять навчання за програмою підготовки офіцерів медичної служби запасу.

За час проведення АТО/ООС на 8-х курсах ППКМС пройшли навчання 677 лікарів (провізорів), з них (осіб):

офіцерів запасу, прийнятих на військову службу в умовах мобілізації, - 586;

офіцерів запасу, прийнятих на військову службу за контрактом, - 35;

офіцерів-резервістів першої черги

оперативного резерву (ОР 1) - 16;

офіцерів-резервістів другої черги

оперативного резерву (ОР 2) - 23; осіб сержантського (старшинського) складу 3 вищою медичною освітою на отримання первинного офіцерського звання «молодший лейтенант медичної служби» - 17.

До проведення занять як в умовах навчальних класів, так і в польових умовах залучався науковий i науково-педагогічний персонал (НіНПП) УВМА та Науково-дослідного інституту проблем військової медицини (НДІ ПВМ) УВМА. Рівень підготовки та набутих знань, які офіцери отримали під час допідготовки, дозволив їм у повному обсязі виконувати посадові обов'язки за посадами, в укомплектуванні яких наразі була гостра необхідність.

Фахівці УВМА під керівництвом директора Військово-медичного департаменту (ВМД) Мо України брали активну участь в організації та проведенні міжвідомчої науково-практичної конференції «Проблеми лікувальноевакуаційного і медичного забезпечення в зоні АТО та шляхи їх вирішення», яка відбулася 13 серпня 2015 року в м. Артемівськ.

Крім того, під час численних відряджень лише співробітниками кафедри військової хірургії УВМА протягом 2014-2019 років проведено 9 науково-практичних конференцій у Донецькому (м. Краматорськ) і Луганському (м. Рубіжне) медичних університетах, а також у м. Маріуполь, прочитано близько 50 лекцій цивільним і військовим лікарям, а також виконано понад 500 хірургічних втручань у польових умовах. Також наукові та науковопедагогічні працівники УВМА протягом 20192020 навчального року взяли участь у роботі 19 міжнародних, 33 українських та галузевих наукових конференціях, з'їздах і симпозіумах, в тому числі вебінарах.

Відповідно до розпорядження директора ВМД МО України з 2016 року НПП УВМА розпочав проведення виїзних циклів ТУ і ПАЦ для військових лікарів та молодших спеціалістів 3 медичною (фармацевтичною) освітою безпосередньо в районах проведення АТО/ООС. Зокрема було організовано навчання військових лікарів та молодших спеціалістів 3 медичною (фармацевтичною) освітою на базі 66 ВМГ (м. Покровськ).

3 метою вдосконалення навчального процесу та врахування у навчанні сучасних підходів надання медичної допомоги під час бойової хірургічної травми і терапевтичної патології з 2017 року в УВМА запроваджені новітні курси ТУ з підвищення кваліфікації (відповідно до протоколів, розроблених Департаментом військової медицини США), а 
came:

на кафедрі військової хірургії: «Хірургічна тактика «damage control surgery» при пораненнях та травмах», «Догляд за пораненими та травмованими «Trauma nursing», «Надання медичної допомоги при термічних ураженнях «Burn patient care»;

на кафедрі військової терапії - «Психічна травма при бойових діях та терористичних актах»;

на кафедрі організації медичного забезпечення збройних сил - «Робота медичного персоналу при масових санітарних втратах»;

на кафедрі авіаційної, морської медицини та психофізіологї - «Базовий курс підготовки інструкторів з медичною освітою»;

на кафедрі анестезіології та реаніматології «Невідкладна медична допомога при бойовій травмі за стандартами ATLS (Advanced Trauma Life Support) та DCR (Damage Control Resuscitation)»;

на кафедрі військової токсикології, радіології та медичного захисту: «Методологія оцінки обстановки та захисту за стандартами НАТО в умовах радіаційних загроз та тероризму», «Методологія оцінки обстановки та захисту за стандартами НАТО в умовах хімічних загроз та тероризму».

За період 2014-2020 років в УВМА закінчили ад'юнктуру 10 з 11 офіцерів (один звільнений за станом здоров'я). Кількість випускників ад'юнктури, які успішно закінчили навчання за 5 останніх років, становить 91,6 \% від загальної кількості випускників, що відповідає вимогам (отримали дипломи 63,6 \%). Всі ад'юнкти були призначені на посади до структурних підрозділів УВМА. На цей час УВМА здійснює підготовку 9 ад’юнктів. 32015 року тематика дисертаційних робіт пов'язана виключно з вирішенням актуальних завдань медичної служби ЗС України під час медичного забезпечення військ в умовах АТО/ООС.

На всіх факультетах і кафедрах УВМА внесено необхідні зміни до програм навчальних дисциплін, а також розроблено нові програми навчальних дисциплін, в яких враховано практичний досвід організації медичного забезпечення бойових дій військ в умовах AT0/OOC та досвід надання медичної допомоги пораненим, травмованим, ураженим і хворим 3 бойовою хірургічною i терапевтичною патологією.

Крім того, НіНПП УВМА видано велику кількість монографій, підручників та навчальних посібників, методичних рекомендацій та нормативних документів, підготовлено наукових статей і тез доповідей 3 актуальних питань військової медицини 3 урахуванням практичного досвіду медичного забезпечення бойових дій військ в умовах АТО/ООС та досвіду надання медичної допомоги пораненим, травмованим, ураженим і хворим 3 бойовою хірургічною і терапевтичною патологією. Так, тільки за останні два роки видано:

монографій - 11;

підручників та навчальних посібників - 42;

методичних рекомендацій та нормативних документів - 16;

наукових статей - 362;

тез доповідей - 217.

За дорученням ВМД МО України та Центрального військово-медичного управління Збройних Сил України (з 2018 року - Головного військово-медичного управління, а на цей час Командування Медичних сил) протягом останніх років НіНПП УВМА виконано більше 350 оперативних завдань, за результатами котрих розроблено проекти ряду нормативноправових актів та керівних документів, які встановленим порядком затверджено на рівні Кабінету Міністрів України, МО України та Генерального штабу Збройних Сил України.

За час проведення АТО/ООС відбулося переосмислення завдань наукової діяльності у сфері охорони здоров'я військовослужбовців, зокрема в частині вирішення актуальних проблем військової медицини та якнайшвидшого практичного впровадження результатів наукових досліджень у практику медичного забезпечення бойових дій військ 3 метою надання своєчасної та ефективної медичної допомоги пораненим, ураженим, травмованим і хворим військовослужбовцям 3 бойовою хірургічною та терапевтичною патологією. Набули актуальності фундаментальні та прикладні наукові дослідження проблем збереження психічного здоров'я військовослужбовців, зокрема психодіагностика та медико-психологічна реабілітація військовослужбовців в умовах AT0/00C, психотехнології захисту від інформаційного впливу та маніпулювання свідомістю, а також методології прогнозування професійної придатності до екстремальних умов діяльності людини.

За роки існування НДІ ПВМ УВМА в ньому виконано понад 100 науково-дослідних робіт та більше 1000 оперативних завдань з актуальних питань медичного забезпечення ЗС України в особливий період. В межах провадження 
зазначених робіт виконано 5 дисертаційних досліджень на здобуття наукового ступеня доктора медичних наук та більше 30 кандидата медичних наук, отримано понад 30 патентів на винаходи.

На цей час активно розвивається такий вид діяльності НДІ ПВМ УВМА, як наукове обгрунтування медико-технічних вимог до нових зразків евако-транспортних засобів, у тому числі броньованої та для аеромедичної евакуації, спеціальної медичної техніки (рухомих кабінетів хірургічних та рентгенівських) тощо, які представляють інтерес та вкрай необхідні для медичної служби 3С України в особливий період. Також здійснюється науковий супровід їх розробки та участь у випробуваннях і дослідній експлуатації.

Крім того НіНПП УВМА залучений до створення нових і вдосконалення існуючих медичних підрозділів та військово-медичних закладів і відпрацювання організаційних засад ï застосування, a саме: розробка сучасних організаційно-штатних структур ВМГ та передової хірургічної групи (ПХГ). Так на цей час опрацьовано «Настанову із застосування військового мобільного госпіталю на особливий період» $\mathrm{i}$ «Тимчасове положення з організації та функціонування передової хірургічної групи». В травні 2020 року 20 слухачів та 18 НіНПП УВМА приймали участь в розгортанні та організації роботи 300 ліжкового інфекційного госпіталю на базі ВМГ на полігоні «Дівички». У вересні 2020 року у ході стратегічного командно-штабного навчання «Об'єднані зусилля-2020» на полігоні «Ягорлик» за участі НіНПП УВМА проведені тактико-спеціальні навчання з розгортання та організації роботи ВМГ та ПХГ. В ході зазначених навчань проведено наукові дослідження щодо встановлення оптимальної організаційноштатної структури ВМГ (приймало участь більше 60 офіцерів із числа НіНПП та слухачів) та ПХГ (приймало участь 3 НіНПП та 7 слухачів), їх комплектно-табельного оснащення, організації роботи функціональних підрозділів, спроможностей до висування в райони розгортання та автономного функціонування в польових умовах.

Поруч з великої за обсягом та важливої за змістом навчальної і наукової роботи в УВМА проводиться і патріотично-виховна робота. Так у 2014-2019 роках творчий колектив УВМА взяв активну участь у проведенні військовопатріотичних заходів у військово-медичних закладах та військових частинах в районах проведення АТО/ООС, ВМКЦ регіонів, урочистостях у Національному меморіальному комплексі «Музей історії Другої світової війни 1939-1945 років» та Центральному будинку офіцерів Збройних Сил України.

Відповідно до Указу Президента України від 23 серпня 2015 року № 497/2015 «Про відзначення Дня захисника України» з метою вшанування військових медиків, які сумлінно виконували військовий обов'язок в районах проведення АТО, надавали медичну допомогу пораненим, ураженим, травмованим і хворим військовослужбовцям $3 \mathrm{C}$ України та формування в особового складу медичної служби національної гідності, патріотизму, духовності, військово-професійних якостей, необхідних для виконання бойових завдань за призначенням, з 9 по 18 жовтня 2015 року було проведено військово-патріотичний тур «Військові медики з піснею у серці на варті життя» в Донецькій та Луганській областях за маршрутом: Київ - Харків - Слов'янськ Краматорськ - Сватово - Часів Яр - Бахмут (Красноармійськ) - Нікольське (Володарське) Маріуполь з відвіданням 59, 61, 65 та 66 ВМГ, медичних підрозділів військових частин, середніх загальноосвітніх шкіл Донецької та Луганської областей.

Крім навчальної роботи фахівцями УВМА проведено десятки виїздів в райони проведення ATO/OOC з метою надання практичної допомоги в організації медичного забезпечення військ та надання медичної допомоги пораненим, ураженим, травмованим і хворим військовослужбовцям. Також науковий та науково-педагогічний персонал УВМА на ротаційній основі виконував завдання в органах управління оперативних угруповань військ (сил) та у ВМГ.

За безпосередню участь в медичному забезпечення 3С України за час проведення ATO/OOC статус учасника бойових дій набули 76 осіб постійного складу та 75 слухачів УВМА.

Визнанням вагомого вкладу в медичне забезпечення ЗС України під час АТО/ООС $€$ нагородження та заохочення особового складу УВМА за останні шість років, а саме:

державними нагородами - 14;

відзнаки Президента України - 46;

відзнаки Міністра оборони України - 142; відзнаки Генерального штабу Збройних Сил України - 67;

грамота Міністра оборони України - 13;

грамота ВМД МО України - 164;

подяка ВМД МО України - 172;

отримали військові звання на 1 ступінь вище від посади - 27.

Таким чином, УВМА зроблено значний 
внесок у медичне забезпечення 3С України під час АTO/OOC зокрема в питання комплектування Медичних сил підготовленим медичним персоналом, надання медичної

\section{Висновки}

1. УВМА $€$ основою військово-медичної освіти в Україні і забезпечує підготовку, перепідготовку та підвищення кваліфікації медичного персоналу за необхідними спеціальностями всіх освітньокваліфікаційних рівнів для потреб ЗС України та інших військових формувань.

2. За час проведення АТО/OОC на всіх факультетах та кафедрах УВМА внесено необхідні зміни до освітніх програм і програм навчальних дисциплін, а також розроблено нові програми навчальних дисциплін, в яких враховано практичний досвід організації медичного забезпечення бойових дій військ та

\section{Література}

1. Указ Президента України від 14 березня 2016 року № 92/2016 «Про рішення Ради національної безпеки і оборони України від 4 березня 2016 року «Про Концепцію розвитку сектору безпеки і оборони України».

2. Постанова Кабінету Міністрів України від 31.10.2018 року № 910 «Про затвердження Воєнномедичної доктрини України».

3. Медичне забезпечення Збройних Сил України: стан та погляди на перспективи розвитку. Монографія / Верба А.В., Жаховський В.О., Лівінський В.Г. / Київ: «Видавництво Людмила». - 2017. - 420 с.

4. Закон України від 1 липня 2014 року № 1556-VII «Про вищу освіту» (Відомості Верховної Ради (ВВР), 2014, № 37-38, ст.2004).

5. Наказ Міністерства оборони України від 27.05 .2015 р. № 240 «Про затвердження Положення про вищі військові навчальні заклади».

6. Наказ Міністерства оборони України від

\section{References}

1. Decree of the President of Ukraine «On the decision of the National Security and Defense Council of Ukraine of March 4, 2016», March 14, 2016 № 92/2016 «On the Concept of Development of the Security and Defense Sector of Ukraine». Official Gazette of the President of Ukraine, April 5, 2016, 10, page 3, article 195- Retrived on 03.10.2020. Access mode: https://zakon.rada.gov.ua/laws/show/92/ 2016\#Text.

2. Resolution of the Cabinet of Ministers of Ukraine «On approval of the Military Medical Doctrine of Ukraine», October 31, 2018 № 910. Official Gazette of Ukraine, November 16, 2018, № 88, page 105, article 2930 Retrived on 03.10.2020. - Access mode: https://zakon.rada.gov.ua/laws/show/910-2018-п\#Text

3. Verba, A.V., Zhakhovskyi, V.O., Livinskyi, V.G. (2017) Medical support of the Armed Forces of Ukraine: state and views on the prospects of development. Monograph. K.: SPD Chalchynska N.V. $420 \mathrm{p}$.

4. Law of Ukraine «On Higher Education», July 1, 2014 допомоги пораненим, ураженим, травмованим і хворим військовослужбовцям та наукового вирішення проблем медичного забезпечення військ в умовах бойових дій.

досвід надання медичної допомоги пораненим, травмованим, ураженим і хворим військовослужбовцям з бойовою хірургічною і терапевтичною патологією.

3. Наукову діяльність в УВМА спрямовано на виконання завдань в частині вирішення актуальних проблем військової медицини та якнайшвидшого практичного впровадження результатів наукових досліджень у практику медичного забезпечення бойових дій військ 3 метою надання своєчасної та ефективної медичної допомоги пораненим, ураженим, травмованим і хворим військовослужбовцям під час АТО/OOC.

09.01.2020 p. № 4 «Про затвердження Положення про особливості організації освітньої діяльності у вищих військових навчальних закладах Міністерства оборони України та військових навчальних підрозділах закладів вищої освіти».

7. Звіт про роботу Української військово-медичної академії за 2013-2014 навчальний рік.

8. Звіт про роботу Української військово-медичної академії за 2014-2015 навчальний рік.

9. Звіт про роботу Української військово-медичної академії за 2015-2016 навчальний рік.

10. Звіт про роботу Української військово-медичної академії за 2016-2017 навчальний рік.

11. Звіт про роботу Української військово-медичної академії за 2017-2018 навчальний рік.

12. Звіт про роботу Української військово-медичної академії за 2018-2019 навчальний рік.

13. Звіт про роботу Української військово-медичної академії за 2019-2020 навчальний рік.

№ 1556-VII, Revision on September 25, 2020, on the basis - 849-IX. Vidomosti Verkhovnoi Rady, 2014, 37-38, page 2716, article 2004. - Retrived on 03.10.2020. - Access mode: $\quad$ https://zakon.rada.gov.ua/laws/show/155618?lang=en\#Text.

5. Order of the Ministry of Defense of Ukraine dated 27.05.2015 № 240 «On approval of the Regulations on higher military educational institutions». Official Gazette of Ukraine, July 21, 2015, № 55, page 858, article 1819.Retrived on 03.10.2020. - Access mode: https://zakon.rada.gov.ua/laws/show/z0706-

15?lang=en\#Text

6. Order of the Ministry of Defense of Ukraine dated 20.07.2015 № 346 «On approval of the Regulations on the peculiarities of the organization of educational activity in the higher military educational institutions of the Ministry of Defense of Ukraine and military educational divisions of the higher education institutions». Official Gazette of Ukraine, March 20, 2020, № 22, page 55, article 826.- 
Retrived on 03.10.2020. - Access mode: https://zakon.rada.gov.ua/laws/show/z0250-

20?lang=en\#Text

7. Report of the Ukrainian Military Medical Academy activity for the 2013-2014 academic year.

8. Report of the Ukrainian Military Medical Academy activity for the 2014-2015 academic year.

9. Report of the Ukrainian Military Medical Academy activity for the 2015-2016 academic year.
10. Report of the Ukrainian Military Medical Academy activity for the 2016-2017 academic year.

11. Report of the Ukrainian Military Medical Academy activity for the 2017-2018 academic year.

12. Report of the Ukrainian Military Medical Academy activity for the 2018-2019 academic year.

13. Report of the Ukrainian Military Medical Academy activity for the 2019-2020 academic year.

\title{
РОЛЬ И ВКЛАД УКРАИНСКОЙ ВОЕННО-МЕДИЦИНСКОЙ АКАДЕМИИ В МЕДИЦИНСКОЕ ОБЕСПЕЧЕНИЕ ВООРУЖЕННЫХ СИЛ УКРАИНЫ ВО ВРЕМЯ АТО / ООС
}

\section{А.Н. Галушка' ${ }^{1}$ В.Л. Савицкий ${ }^{2}$, В.А. Жаховский ${ }^{2}$ В.Г. Ливинский ${ }^{2}$}

${ }^{1}$ Командование Медицинских сил Вооруженных сил Украины г. Киев, Украина

2 Украинская военно-медицинская академия г. Киев, Украина

Цель работы - исследование роли и вклада Украинской военно-медицинской академии (УВМА) в медицинское обеспечение Вооруженных Сил (BC) Украины во время антитеррористической операции и операции Объединенных сил (АТО / OOC).

Материалы и методы. Использованы нормативно-правовые акты по вопросам национальной безопасности государства и охраны здоровья в Украине, руководящие документы Министерства обороны Украины, публикации в открытых научных источниках, ежегодные отчеты УВМА. Объект исследования система подготовки медицинского персонала для Медицинских сил Вооруженных Сил Украины (Медицинские силы). Предмет исследования - работа УВМА по подготовке медицинского персонала для Медицинских сил и научного сопровождения развития системы медиџинского обеспечения ВС Украины во время АТО / ООС.

Методы исследования - библиографический, статистический, аналитический, системного подхода.

Результаты. Вклад УВМА в медицинское обеспечение ВС Украины не сводился только кучебной работе по подготовке военных врачей для нужд воинских частей и военно-медицинских учреждений, а также был весомым и значимым в таких направлениях деятельности военной медицины как практическое оказание медицинской помощи раненым, травмированным и больным военнослужащим в военно-медищинских учреждениях в районах проведения АТО / ООС и на клинических базах УВМА, в вопросах научного сопровождения развития системы медицинского обеспечения ВС Украины, в том числе разработка нормативно-правовых и руководящих документов по медицинскому обеспечению, медико-технических требований к современным образцам эвакуационнотранспортных средств, специальной медищинской техники, комплектно-табельного оснащения Медищинских сил и индивидуальных средств медицинской защиты.

Выводы. УВМА сделан значительный вклад в медицинское обеспечение ВС Украины во время АТО / ООС в частности по вопросам комплектования Медицинских сил подготовленным медицинским персоналом, оказанию медицинской помощи раненым, травмированным и больным военнослужащим и научного решения проблем медицинского обеспечения войск в условиях боевых действий.

Ключевые слова: медицинское обеспечение, военно-медицинское образование и наука, УВМА.

\section{ROLE AND CONTRIBUTION OF UKRAINIAN MILITARY MEDICAL ACADEMY IN THE MEDICAL SUPPORT OF THE ARMED FORCES OF UKRAINE DURING ATO / JFO}

\author{
A.M. Halushka', V.L. Savytskyi², V.0. Zhakhovsky ${ }^{2}$, V.G. Livinskyi² \\ ${ }^{1}$ Medical Forces Command of the Armed Forces of Ukraine, Kyiv, Ukraine \\ 2 Ukrainian Military Medical Academy, Kyiv, Ukraine
}

The purpose of the work is to study the role and contribution of the Ukrainian Military Medical Academy (UMMA) in the medical support of the Armed Forces (AF) of Ukraine during the Anti-Terrorist Operation and the Joint Forces Operation (ATO / JFO)

Materials and methods. Regulations on national security and health care in Ukraine, guiding documents of the Ministry of Defense of Ukraine, publications in open scientific sources, annual reports of UMMA were used. The object of research is the system of training medical personnel for the Medical Forces of the Armed Forces of Ukraine (Medical Forces). The subject of the research is the work of UMMA on the training of medical personnel for the Medical Forces and scientific support of the development of the medical support system of the Armed Forces of Ukraine during the ATO / JFO. Research methods - bibliographic, statistical, analytical, systems approach.

Results. UMMA's contribution to the medical support of the Armed Forces of Ukraine was not limited to the training of military doctors for the needs of military units and military medical institutions, but also was significant in such areas of military medicine as practical medical care for wounded, injured, and sick servicemen in military medical institutions in the areas of anti-terrorist operation / environmental protection and at clinical bases of UMMA, 
in matters of scientific support of the development of the medical system of the Armed Forces of Ukraine, including development of legal and guiding documents on medical support, medical and technical requirements of modern models of evacuation vehicles, special medical equipment, complete equipment of the Medical Forces and individual means of medical protection.

Conclusions. UMMA made a significant contribution to the medical support of the Armed Forces of Ukraine during the ATO / JFO, in the issue of staffing the Medical Forces with trained medical personnel, providing medical care to wounded, injured, and sick servicemen and scientific solutions to medical care in combat environment.

Key words: medical support, military medical education and science, UMMA.

Конфлікт інтересів: відсутній.

Conflicts of interest: authors have no conflict of interest to declare.

\section{Відомості про авторів:}

Галушка А.М. А,Е,F- полковник медичної служби, доктор медичних наук, професор, начальник штабузаступник командувача Медичних сил Збройних Сил України, м. Київ.

Савицький В.Л. A,B,C,D,E - полковник медичної служби, доктор медичних наук, професор, начальник Української військово-медичної академії, м. Київ.

Жаховський В.О. B,C,D,E - к.н.держ.упр., доц., провідний науковий співробітник Науково-дослідного інституту проблем військової медицини Української військово-медичної академії, м. Київ.

Лівінський В.Г. В,C,D,E - к.мед.Н., провідний науковий співробітник Науково-дослідного інституту проблем військової медицини Української військово-медичної академії, м. Київ.

$A$ - концепція та дизайн дослідження; $B$ - збір даних; $C$ - аналіз та інтерпретація даних;

$D$ - написання статmi; $E$ - редагування статmi; F- остаточне затвердження статті.

Сведения об авторах:

Галушка А.М. - полковник медицинской службы, доктор медицинских наук, профессор, начальник штаба- заместитель командующего Медицинских сил Вооруженных Сил Украины, г. Киев.

Савицкий В.Л. - полковник медицинской службы, доктор медицинских наук, профессор, начальник Украинской военно-медицинской академии, г. Киев.

Жаховский В.А. - к.н. держ. упр., доц., ведущий научный сотрудник Научно-исследовательского института проблем военной медицины Украинской военно-медицинской академии, г. Киев.

Ливинский В.Г. - к.мед.н., ведущий научный сотрудник Научно-исследовательского института проблем военной медицины Украинской военно-медицинской академии, г. Киев.

\section{Information about authors:}

Halushka A.M. A, E, F - Col. MS, Doctor of Medical Sciences, Professor, Chief of Staff - Deputy Commander of the Medical Forces of the Armed Forces of Ukraine. https://orcid.org/0000-0003-3530-0946, Kyiv.

Savytskyi V.L. A,B,C,D,E - Col. MS, Doctor of Medical Sciences, Professor, Chief of Ukrainian Military Medical Academy, Email: savvalleon@ukr.net, https://orcid.org/0000-0001-8027-0163, Kyiv.

Zhakhovsky V.0. B,C,D,E - candidate of science in public administration, associate professor, Research Institute of Military Medicine of the Ukrainian Military Medical Academy, leading researcher of research department of medical support organization, Email: zhahovskiy-viktor@ukr.net, https://orcid.org/0000-0002-2665-2766, Kyiv

Livinskyi V.G. B,C,D,E,- candidate of medical sciences, Research Institute of Military Medicine of the Ukrainian Military Medical Academy, leading researcher of the research department of medical standardization and metrological support, Email: v.livinskiy@gmail.com, https://orcid.org/0000-0002-1102-1128, Kyiv

$A$ - research concept and design; $B$ - collection and/or assembly of data; $C$ - data analysis and interpretation; $D$ writing the article; $E$ - critical revision of the article; $F$ - final approval of the article.

Адреса для листування: вул. Московська, 45/1, буд. 33, м. Київ 01015 